\title{
Perancangan Pemasaran Industri Kreatif Sub-Sektor Kuliner Dalam Mendukung Pertumbuhan Ekonomi Daerah
}

\author{
Endra Yuafanedi Arifianto ${ }^{1}$, Oke Oktavianty ${ }^{2}$, Ishardita Pambudi \\ Tama $^{3}$, Sari Fitri Safira ${ }^{4}$, Lailatul Fajriyati ${ }^{5}$ \\ Jurusan Teknik Industri, Universitas Brawijaya1 \\ email korespondensi: endra@ub.ac.id
}

\begin{abstract}
Abstrak: Persaingan ketat di industri kreatif sub-sektor kuliner saat ini menjadi fokus utama pemerintah. Dibentuknya klasterisasi bertujuan untuk memberikan sinergi antar pelaku usaha dan mengembangkan industri kreatif. Kota Malang mengalami pertumbuhan yang signifikan pada industri kreatif subsektor kuliner dalam dua tahun terakhir. Dimana 20.000 pendatang berupa mahasiswa baru per tahunnya dapat menjadi target pasar yang tepat bagi pelaku usaha industri kreatif sub-sektor kuliner. Selain itu dukungan alokasi dana desa menjadikan Malang menjadi lokasi yang strategis untuk membuka transaksi jual beli atau sewa guna usaha industri kreatif pada sub-sektor kuliner. Dalam penelitian ini ditentukan faktor bauran pemasaran yakni harga, produk, tempat, promosi, bukti fisik, SDM, dan tempat pada industri kreatif sub-sektor kuliner yang paling dominan guna mempengaruhi keputusan masyarakat untuk membeli dan menjadi konsumen. Metode yang digunakan adalah analisis bauran pemasaran dengan Smart PLS yang berguna untuk menghitung dan menentukan faktor yang paling berpengaruh terhadap keputusan masyarakat dalam membeli produk dan menjadi pelanggan. Hasil yang didapat dari analisis menggunakan perangkat lunak Smart PLS yakni diperoleh faktor paling dominan berupa aspek proses dengan nilai koefisien 0,538. Kemudian diikuti dengan aspek tempat dengan nilai koefisien sebesar 0,415.
\end{abstract}

Kata kunci: Industri Kreatif, Bauran Pemasaran, Smart PLS.

Dewasa ini persaingan industri kreatif dapat dikatakan sangat ketat. Dengan memperhatikan hal tersebut, pemerintah mengambil langkah dengan membuat beberapa kebijakan tentang pengembangan dan klasterisasi dalam rangka mendukung pertumbuhan industri kreatif baik dalam skala mikro, kecil dan menengah di daerah. Dalam konsep klasterisasi, pemerintah bekerjasama bersama para pelaku usaha (masyarakat) dengan saling mendukung dan saling bersinergi. Pemangku kepentingan yang bersinergi dalam industri kreatif diharapkan akan mendorong kemampuan sehingga dapat menciptakan daya saing. Konsep bersinergi yang dimaksud merupakan sebuah konsep yang menjadikan usaha sejenis sebagai mitra diharuskan untuk bertumbuh bersama dengan tidak menjadikan pesaing dan saling menjatuhkan ataupun mematikan satu sama lain. Namun dengan munculnya beberapa permasalahan industri kreatif seperti rendahnya akses terhadap sumber daya produktif seperti modal, bahan baku, informasi, rendahnya kualitas sumberdaya manusia, rendahnya produktivitas, tingginya biaya transaksi/biaya usaha, rendahnya akses dan penerapan teknologi. Dari permasalahan tersebut masih diperlukan pendampingan berkala oleh pemerintah dan akademisi untuk memajukan industri kreatif sub-sektor kuliner.

Untuk itu, fokus dari pembahasan ini adalah menciptakan industri kreatif yang memanfaatan kreativitas, keterampilan serta bakat individu 
untuk menciptakan kesejahteraan serta lapangan pekerjaan dengan menghasilkan dan mengeksploitasi daya kreasi dan daya cipta individu tersebut. Industri kreatif sendiri dikelompokkan oleh Pemerintah Indonesia kedalam 16 sub sektor, salah satu nya yakni sub-sektor kuliner yang memiliki perkembangan pesat dalam beberapa dekade terakhir ini. Subsektor ini selalu diminiati sebab kuliner merupakan pokok dan selalu dibutuhkan oleh masyarakat luas, serta pemanfaatan daya cipta kreasi yang luas selalu menjadi andalan dan daya tarik dalam sub-sektor ini. Salah satu kota yang memiliki potensi yang baik adalah Kota Malang yang terkenal sebagai kota pendidikan, dimana kota ini memiliki potensi kebutuhan kuliner terus meningkat dikarenakan setiap tahunnya banyak pendatang seperti mahasiswa baru yang mencapai 20.000 orang, peluang ini dianggap sebagai sasaran yang baik untuk sub-sektor kuliner.

Beberapa tahun terakhir pertumbuhan industri kreatif sub-sektor kuliner mengalami trend positif pada permintaan dan penawaran. Program pemerintah tentang Alokasi Dana Desa dan pembuatan Badan Usaha Milik Desa juga menjadi salah satu peluang untuk industri kreatif berkembang di daerah, yakni dengan memperbesar peran masyarakat secara luas. Pemanfaatan lahan di daerah perbatasan Kota Malang (pinggiran) dapat dijadikan area yang startegis untuk pengembangan industri kreatif.

Sehingga melihat potensi yang ada, tim peneliti mengadakan riset terhadap industri kreatif sub-sektor kuliner melalui penyebaran kuesioner kepada responden dan juga manajemen untuk mengevaluasi serta memaksimalkan potensi yang dimiliki industri untuk mengembangkan teknik pemasaran untuk mendukung pertumbuhan ekonomi daerah.

\section{METODE}

Penelitian ini termasuk penelitian kuantitatif dan juga penelitian kualitatif. Penelitian kuantitatif karena dilakukan penghitungan data menggunakan Smart PLS pada respon pelanggan maupun manajemen yang bersifat kualitatif. Metode perhitungan dengan Smart PLS meninjau aspek-aspek dalam bauran pemasaran yaitu 7P (Product, Price, Promotion, Place, People, Process, Physical Evidence) untuk dilakukan analisis lebih lanjut terhadap data.

\section{HASIL}

Pada hasil riset terhadap industri kreatif, identitas responden diketahui berdasarkan jenis kelamin, usia dan status seperti data yang tertera di bawah ini.

Tabel 1. Lokasi Penelitian

\begin{tabular}{llll}
\hline No & Pertanyaan & & Jumlah \\
\hline 1 & Jenis Kelamin & Laki-laki & 13 \\
& & Perempuan & 27 \\
2 & Usia & $17-30$ & 32 \\
3 & Status & $>30$ & 8 \\
\hline
\end{tabular}


Kuesioner yang disebarkan terdiri dari 61 pertanyaan mengenai bauran pemasaran 7P, faktor internal, dan faktor eksternal yang dapat mempengaruhi perkembangan usaha di sektor kuliner. Pertanyaan tersebut diisi dan dinilai oleh responden menggunakan skala likert (1-4).

Berikut merupakan instrumen bauran pemasaran 7P yang digunakan sebagai aspek penilaian responden pada penelitian industri kreatif subsektor kuliner.

Tabel 2. Instrumen Bauran Pemasaran 7P

\begin{tabular}{|c|c|}
\hline Variabel & Instrument / Pertanyaan \\
\hline \multicolumn{2}{|l|}{ Product } \\
\hline 1. & $\begin{array}{l}\text { Produk yang ada pada Industri Kreatif Sub Sektor Kuliner } \\
\text { (warung/kafe/resto) memiliki kualitas rasa yang baik }\end{array}$ \\
\hline 2. & $\begin{array}{l}\text { Produk yang tersedia di Industri Kreatif Sub Sektor Kuliner } \\
\text { (warung/kafe/resto) memiliki varian yang beraneka ragam dan } \\
\text { mencukupi kebutuhan konsumen }\end{array}$ \\
\hline 3. & $\begin{array}{l}\text { Produk Industri Kreatif Sub Sektor Kuliner (warung/kafe/resto) } \\
\text { hasil petani lokal }\end{array}$ \\
\hline 4. & $\begin{array}{l}\text { Produk Industri Kreatif Sub Sektor Kuliner (warung/kafe/resto) } \\
\text { bisa di bungkus dengan Desain kemasan yang menarik }\end{array}$ \\
\hline 5. & $\begin{array}{l}\text { Desain merk dan label pada produk yang disediakan Industri } \\
\text { Kreatif Sub Sektor Kuliner (warung/kafe/resto) sudah menarik }\end{array}$ \\
\hline \multicolumn{2}{|r|}{ 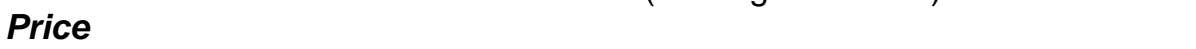 } \\
\hline 6. & $\begin{array}{l}\text { Harga jual produk Industri Kreatif Sub Sektor Kuliner } \\
\text { (warung/kafe/resto) terjangkau konsumen }\end{array}$ \\
\hline 7. & $\begin{array}{l}\text { Industri Kreatif Sub Sektor Kuliner (warung/kafe/resto) selalu } \\
\text { memiliki kebijakan potongan harga }\end{array}$ \\
\hline 8. & Harga produk sangat kompetitif dengan pesaing \\
\hline 9. & $\begin{array}{l}\text { Harga produk sesuai dengan kualitas bahan dan tingkat } \\
\text { kesulitan pembuatan }\end{array}$ \\
\hline 10. & $\begin{array}{l}\text { Setiap momen/event istimewa pengunjung/konsumen } \\
\text { mendapat potongan harga khusus (misal pas tanggal ulang } \\
\text { tahun konsumen dengan menunjukkkan KTP) }\end{array}$ \\
\hline $\begin{array}{l}11 . \\
\text { Place }\end{array}$ & Ada diskon besar ketika event hari raya besar atau HUT RI \\
\hline & Proses pendistribusian produk dari Industri Kreatif Sub Sektor \\
\hline 12. & $\begin{array}{l}\text { Kuliner (warung/kafe/resto) kepada konsumen tergolong } \\
\text { efektif dan mudah }\end{array}$ \\
\hline 13. & Lokasi strategis mudah dijangkau/dipinggir jalan yang ramai \\
\hline 14. & $\begin{array}{l}\text { Tempat Industri Kreatif Sub Sektor Kuliner (warung/kafe/resto) } \\
\text { sangat nyaman, bersih dan menarik }\end{array}$ \\
\hline 15. & $\begin{array}{l}\text { Lokasi Industri Kreatif Sub Sektor Kuliner (warung/kafe/resto) } \\
\text { bisa di cek di google maps }\end{array}$ \\
\hline
\end{tabular}

Tabel 3. Instrumen Bauran Pemasaran 7P (lanjutan)

\begin{tabular}{ll}
\hline Variabel & Instrument / Pertanyaan \\
\hline Promotion & \\
16. & $\begin{array}{l}\text { Industri Kreatif Sub Sektor Kuliner (warung/kafe/resto) } \\
\text { melakukan promosi secara online melalui media sosial }\end{array}$ \\
17. & $\begin{array}{l}\text { Industri Kreatif Sub Sektor Kuliner (warung/kafe/resto) } \\
\text { melakukan promosi offline dari beberpa event atau dari mulut }\end{array}$ \\
\hline
\end{tabular}




\begin{tabular}{|c|c|}
\hline & ke mulut \\
\hline 18. & $\begin{array}{l}\text { Industri Kreatif Sub Sektor Kuliner (warung/kafe/resto) } \\
\text { memiliki papan iklan di beberapa tempat startegis }\end{array}$ \\
\hline 19. & $\begin{array}{l}\text { Industri Kreatif Sub Sektor Kuliner (warung/kafe/resto) } \\
\text { memiliki papan publikasi di depan lokasinya }\end{array}$ \\
\hline 20. & $\begin{array}{l}\text { Industri Kreatif Sub Sektor Kuliner (warung/kafe/resto) } \\
\text { promosi melalui radio dan TV lokal }\end{array}$ \\
\hline \multicolumn{2}{|l|}{ People } \\
\hline 21. & $\begin{array}{l}\text { Tim Industri Kreatif Sub Sektor Kuliner (warung/kafe/resto) } \\
\text { bersikap sangat ramah, murah senyum dan menyenangkan }\end{array}$ \\
\hline 22. & $\begin{array}{l}\text { Tim Industri Kreatif Sub Sektor Kuliner (warung/kafe/resto) } \\
\text { sangat terampil dalam membuat produk }\end{array}$ \\
\hline 23. & $\begin{array}{l}\text { Sebagai pelanggan terpuaskan dengan pelayanan yang cepat } \\
\text { dan cekatan }\end{array}$ \\
\hline 24. & $\begin{array}{l}\text { Industri Kreatif Sub Sektor Kuliner (warung/kafe/resto) } \\
\text { pegawainya berpakaian sopan dan elegan }\end{array}$ \\
\hline 25. & $\begin{array}{l}\text { Pegawai Industri Kreatif Sub Sektor Kuliner } \\
\text { (warung/kafe/resto) mampu menterjemahkan dan } \\
\text { menjelaskan dengan baik setiap deskripsi produk ke } \\
\text { konsumen }\end{array}$ \\
\hline \multicolumn{2}{|r|}{${ }^{2}$} \\
\hline 26. & $\begin{array}{l}\text { Proses pembuatan/peracikan produk bisa dilihat secara } \\
\text { langsung oleh konsumen }\end{array}$ \\
\hline $\begin{array}{l}27 . \\
28 .\end{array}$ & $\begin{array}{l}\text { Antrian sangat rapi, tertib, dan tersistem dengan baik } \\
\text { Proses pemesanan produk di Industri Kreatif Sub Sektor } \\
\text { Kuliner (warung/kafe/resto) dapat dilakukan dengan mudah }\end{array}$ \\
\hline 29. & Proses pembayaran produk sangat mudah \\
\hline $\begin{array}{l}30 . \\
\text { Physical }\end{array}$ & Melayani proses pemesanan online dan offline \\
\hline 31. & $\begin{array}{l}\text { Tata letak alat produksi Industri Kreatif Sub Sektor Kuliner } \\
\text { (warung/kafe/resto) sangat rapi }\end{array}$ \\
\hline 32. & Memiliki beberapa ruangan yang dibutuhkan konsumen \\
\hline 33. & Sarana dan prasarana lengkap sesuai kebutuhan konsumen \\
\hline 34. & $\begin{array}{l}\text { Desain interior (warna) sangat menarik dan memberi kesan } \\
\text { nyaman }\end{array}$ \\
\hline 35. & Bangunan fisik yang bersih dan berkarakter/unik/khas \\
\hline
\end{tabular}

Setelah melakukan perhitungan instrumen bauran pemasaran oleh konsumen dan manajemen, dilakukan analisis dan pembuatan model konstruk menggunakan Smart PLS. 
Gambar 1. Model Konstruk PLS Industri Kreatif Sub-sektor Kuliner

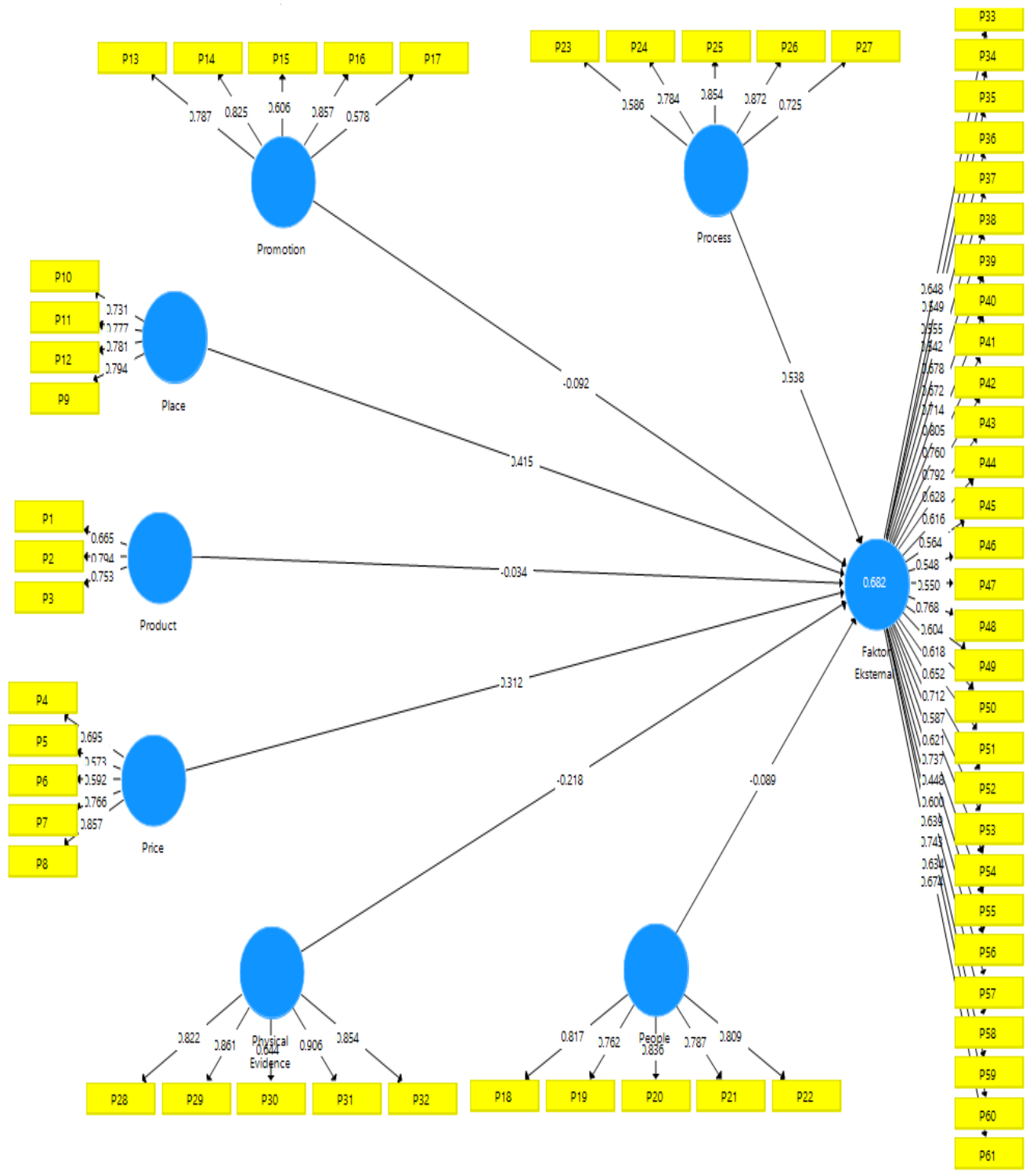

Pada model konstruk dilakukan dua uji salah satunya pengujian outer model yang disebut sebagai model pengukuran. Outer model digunakan untuk uji reliabilitas. Berdasarkan analisis data bauran pemasaran diketahui bahwa P7, P8, P9, P10, P11, P12, P13, P14, P16, P18, 019, P2, P20, P21, P22, P24, P25, P26, P27, P28, P29, P31, P32, memiliki nilai diatas 0,6 yang menandakan indikator tersebut reliable.

Selain itu dilakukan uji inner model yang berfungsi untuk menganalisis hubungan konstruk dan eksogen serta hubugan diantaranya. 


\begin{tabular}{|c|c|c|c|}
\hline \multicolumn{4}{|l|}{ R Square } \\
\hline \multirow[t]{2}{*}{ 眀 Matrix } & 揕直 R Square & ${ }_{1}$ & Copy \\
\hline & \multicolumn{3}{|c|}{ R Square } \\
\hline Faktor Ek.... & & 0.682 & \\
\hline
\end{tabular}

Gambar 2. Pengujian R Square

Berdasarkan gambar diatas diperoleh hasil $R$ square sebesar 0,682 yang menandakan bahwa faktor bauran pemasaran 7P berpengaruh terhadap faktor eksternal.

\section{PEMBAHASAN}

Berikut merupakan tabel hasil uji dari software Smart PLS terhadap hasil dari kuesioner yang telah disebarkan kepada manajemen dan juga konsumen dari industri kreatif sub-sektor kuliner.

Tabel 4. Hasil Uji PLS

\begin{tabular}{|c|c|c|c|c|}
\hline Variabel & $\begin{array}{l}\text { Nilai } \\
\text { Koefisien }\end{array}$ & Ranking & P-value & Keterangan \\
\hline People (P1) & $-0,089$ & 5 & 0,646 & Tidak Berpengaruh \\
\hline $\begin{array}{l}\text { Physical } \\
\text { Evidence } \\
\text { (P2) }\end{array}$ & $-0,218$ & 7 & 0,301 & Tidak Berpengaruh \\
\hline Place (P3) & 0,415 & 2 & 0,026 & Berpengaruh \\
\hline Price (P4) & 0,312 & 3 & 0,178 & Tidak Berpengaruh \\
\hline $\begin{array}{l}\text { Process } \\
\text { (P5) }\end{array}$ & 0,538 & 1 & 0,007 & Berpengaruh \\
\hline $\begin{array}{l}\text { Product } \\
\text { (P6) }\end{array}$ & $-0,034$ & 4 & 0,849 & Tidak Berpengaruh \\
\hline $\begin{array}{l}\text { Promotion } \\
\text { (P7) }\end{array}$ & $-0,092$ & 6 & 0,668 & Tidak Berpengaruh \\
\hline
\end{tabular}

Berdasarkan tabel hasil analisis Smart PLS ditunjukkan bahwa 3 faktor variabel yang dominan dalam menentukan dan mempengaruhi keputusan masyarakat untuk membeli dan jadi pelanggan antara lain adalah 1) Process yaitu pemetaan alur mulai dari produk di produksi hingga sampai ke end-customer; 2) Place yaitu tempat yang dinilai strategis dan bagus; dan 3) Price yaitu harga produk yang dijual.

Sedangkan dari variabel 7P yang paling rendah atau perlu diperhatikan adalah 1) Physical Evidence adalah desain fasilitas fisik yang menjadi peran utama dalam proses sosialisasi konsep tentang tujuan perusahaan untuk mengkomunikasikan komunikasi dalam norma, nilai, peran, perilaku dan pola hubungan antara karyawan dan konsumen; 2) Promotion yaitu promosi yang dilakukan; dan 3) People yaitu sumberdaya manusia yang perlu ditingkatkan skill dan kapasitasnya

Lebih lanjutnya, berdasarkan analisis faktor paling dominan yang diperoleh dari aspek-aspek bauran pemasaran, yang paling mempengaruhi keputusan masyarakat untuk membeli dan menjadi pelanggan adalah variabel proses (P5). Variabel proses diolah 
menggunakan smart PLS dan didapatkan nilai koefisien sebesar 0,538 dan nilai P-value 0,007 . Dalam penjabaran penelitian, saat ini variabel proses memiliki beberapa indikator, diantaranya sebagai berikut.

1. Antrian sangat rapi, tertib, dan tersistem dengan baik

2. Proses pemesanan produk di industri kreatif sub-sektor kuliner dapat dilakukan dengan mudah

3. Proses pembayaran produk sangat mudah

4. Melayani proses pemesanan online dan offline

Empat indikator diatas perlu diperhatikan oleh seluruh elemen dan stakeholder demi keberlangsungan industri kreatif sub-sektor kuliner. Poin kunci indikator diatas adalah proses produksi industri kreatif sub-sektor kuliner. Indikator ini menjadi pilihan responden sebagai faktor yang paling berpengaruh mempengaruhi responden untuk membeli produk dan menjadi pelanggan.

Faktor dominan yang ditemukan selanjutnya adalah variabel place (P3). Variabel place diolah menggunakan Smart PLS dan didapatkan nilai koefisien 0,415 serta nilai $\mathrm{P}$-value 0,026. Dalam penjabarannya di penelitian ini, variabel place memiliki beberapa indikator, diantaranya sebagai berikut.

1. Proses pendistribusian produk dari industri kreatif sub-sektor kuliner kepada konsumen tergolong efektif dan mudah

2. Tempat indsutri kreatif sub-sektor kuliner sangat nyaman, bersih, dan menarik

3. Lokasi industri kreatif sub-sektor kuliner bisa di cek di google maps

Tiga indikator diatas perlu ditinjau oleh seluruh elemen dan stakeholder terkait demi keberlangsungan industri kreatif sub-sektor kuliner. Poin kunci indikator diatas adalah tempat pendistribusian industri kreatif sub-sektor kuliner. Indikator ini menjadi opsi responden sebagai faktor kedua yang paling berpengaruh mempengaruhi responden untuk membeli produk dan menjadi pelanggan.

Faktor dominan yang ditemukan selanjutnya adalah variabel price (P4). Variabel price (P4) diolah menggunakan Smart PLS dan didapatkan nilai koefisien 0,312 serta nilai $P$-value 0,178 . Dalam penjabarannya di penelitian ini, variabel price memiliki beberapa indikator, diantaranya sebagai berikut.

1. Harga produk sangat kompetitif dengan pesaing

2. Harga produk sesuai dengan kualitas bahan dan tingkat kesulitan pembuatan

3. Setiap momen/event istimewa pengunjung/konsumen mendapat potongan harga khusus (misal pas tanggal ulang tahun konsumen dengan menunjukkkan KTP)

4. Ada diskon besar ketika event hari raya besar atau HUT RI

Empat indikator diatas perlu ditinjau oleh seluruh elemen dan stakeholder terkait demi keberlangsungan industri kreatif sub-sektor kuliner. Poin kunci 
indikator diatas adalah harga yang ditawarkan industri kreatif sub-sektor kuliner. Indikator ini menjadi opsi responden sebagai faktor ketiga yang paling berpengaruh mempengaruhi responden untuk membeli produk dan menjadi pelanggan.

Sehingga dengan mengetahui indikator ketiga faktor dominan dalam keputusan responden ketika membeli dan menjadi pelanggan, dilakukan upaya-upaya dalam pengoptimalan faktor dalam proses, place, maupun price dengan cara menambahkan indikator-indikator yang menjadi pokok keputusan responden untuk membeli dan menjadi pelanggan, seperti hal nya melakukan pengoptimalan proses dalam produksi hingga sampai ke tangan pelanggan, melakukan inovasi terbarukan melalui teknologi terbarukan untuk kemudahan penyaluran dari proses produksi dan juga dapat melakukan kebijakan potongan harga.

Untuk faktor yang paling rendah yang diperoleh dari aspek-aspek bauran pemasaran adalah variabel Physical Evidence (P2). Variabel Physical Evidence (P2) diolah menggunakan smart PLS dan diadapatkan nilai koefisien sebesar $-0,218$ dan nilai $P$-value 0,301. Dalam penjabarannya di penelitian ini, variabel Physical Evidence memiliki indikator, yaitu Sarana dan prasarana kurang lengkap memenuhi kebutuhan konsumen.

Indikator tersebut perlu diperhatikan oleh seluruh elemen dan stakeholder demi keberlangsungan industri kreatif sub-sektor kuliner. Poin kunci indikator diatas adalah Physical Evidence dari industri kreatif subsektor kuliner. Indikator ini menjadi pilihan responden sebagai faktor yang paling rendah atau yang perlu diperhatikan

Faktor yang paling rendah yang ditemukan selanjutnya adalah variabel Promosi (P7). Variabel Promosi (P7) diolah menggunakan Smart PLS dan didapatkan nilai koefisien $-0,092$ dan nilai P-value 0,668. Dalam penjabarannya di penelitian ini, variabel place memiliki beberapa indikator, diantaranya sebagai berikut.

1. Industri Kreatif Sub Sektor Kuliner kurang mempromosikan melalui radio dan TV lokal

2. Industri Kreatif Sub Sektor Kuliner (warung/kafe/resto) kurang melakukan promosi offline dari beberpa event atau dari mulut ke mulut

Dua indikator diatas perlu ditinjau oleh seluruh elemen dan stakeholder terkait demi keberlangsungan industri kreatif sub-sektor kuliner. Poin kunci indikator diatas adalah promosi yang dilakukan industri kreatif sub-sektor kuliner. Indikator ini menjadi opsi responden sebagai faktor kedua yang paling berpengaruh mempengaruhi responden untuk membeli produk dan menjadi pelanggan. Indikator ini menjadi pilihan responden sebagai faktor kedua yang paling rendah atau yang perlu diperhatikan.

Sehingga dengan mengetahui indikator kedua faktor yang paling rendah atau yang perlu diperhatikan dalam keputusan responden ketika membeli dan menjadi pelanggan, dilakukan upaya-upaya dalam perbaikan faktor dalam physical evidence maupun promosi, dengan cara 
memperbaiki dan menambahkan indikator-indikator yang menjadi pokok keputusan responden untuk membeli dan menjadi pelanggan, seperti hal nya menyediakan sarana dan prasarana yang memenuhi kebutuhan konsumen, melakukan promosi melalui radio dan TV Lokal, serta melakukan promosi offline dari beberapa event atau mulut ke mulut.

\section{KESIMPULAN}

Dari hasil penelitian didapatkan dua faktor bauran pemasaran 7P yang paling dominan, didapatkan faktor paling dominan yang mempengaruhi keputusan masyarakat untuk membeli dan menjadi pelanggan adalah variabel proses (P5) dengan nilai koefisien 0,538 dan nilai P-value 0,007 . Setelah itu diikuti variabel place (P3) dan didapatkan nilai koefisien sebesar 0,415 dan nilai $P$-value 0,026 . Kemudian diikuti variabel price (P4) dengan nilai koefisien 0,312 dan $P$-value 0,178 . Dari ketiga faktor dominan yang telah diketahui dapat dilakukan pengoptimalan dan inovasi lebih lanjut terhadap aspek dari proses, place, dan price.

Kemudian juga didapatkan faktor yang paling rendah yaitu variabel Physical Evidence (P2) dan didapatkan nilai koefisien sebesar -0,218 dan nilai P-value 0,301. Setelah itu diikuti Variabel Promosi (P7) dan didapatkan nilai koefisien -0,092 dan nilai $P$-value 0,668. Dari kedua faktor yang paling rendah atau yang perlu diperhatikan dalam keputusan responden ketika membeli dan menjadi pelanggan, dapat dilakukan upaya-upaya dalam perbaikan.

\section{DAFTAR PUSTAKA}

Adikusumo. (1986). Pendidikan Kemasyarakatan. Yogyakarta: Pustaka.

Adi, M Kwartono. (2007). Analisis Usaha Kecil dan Menengah. Yogyakarta: Andi Offset

David, Fred R. (2010). Manajemen Strategis Konsep. Jakarta : PT. Prenhallindo

David, Fred R. (2011). Strategic Management, Buku 1. Edisi 12. Jakarta: Salemba Empat

Kotler, P. \& Keller, K. L. (2009). Manajemen Pemasaran, Edisi 13, Jilid I. Jakarta: Penerbit Erlangga.

Kotler, P. \& Armstrong, G. (2012). Prinsip- Prinsip Pemasaran Edisi 12. Jakarta:Erlangga.

Lantu, Donald Crestofel dkk. (2016). Pengembangan Model Peningkatan Daya Saing UMKM di Indonesia : Validasi Kuantitatif Model. Jurnal Manajemen Teknologi, 15(1), 2016, 77-93

Purnomo (2019). Analisis Strategi Dan Pengembangan Produk Unggulan Pada Industri Kecil Menengah Bahan Kaca Di Malang. Jurnal IImiah Teknik Industri, 7(2) 2019, 134 - 139

Rudjito. (2003). Strategi Pengembangan Umkm Berbasis Strategi Bisnis, Makalah Yang Di 
Sampaikan Pada Seminar Peran Perbankan Dalam Memperkokoh Ketahanan Nasional Kerjasama Lemhanas RI Dengan BRI. Jurnal Ekonomi Rakyat

Yoeti, Oka A. (1996). Pengantar Ilmu Pariwisata. Bandung: Angkasa 